\title{
Rhagadodidymellopsis endocarpi gen. et sp. nov. and Arthopyrenia symbiotica (Dothideomyceta), two lichenicolous fungi growing on Endocarpon species
}

\author{
Samantha Fernández-Brime ${ }^{1 *}$, Ester Gaya ${ }^{2}$, Xavier Llimona ${ }^{3}$, Mats Wedin ${ }^{1}$ \\ \& Pere Navarro-Rosinés ${ }^{3}$
}

\section{Article info}

Received: 3 Oct. 2019

Revision received: 3 Feb. 2020

Accepted: 8 Feb. 2020

Published: 2 Jun. 2020

\section{Associate Editor}

Paul Diederich

\begin{abstract}
The lichenicolous fungus Rhagadodidymellopsis endocarpi (Dothideomyceta) growing on the thallus of the terricolous lichen Endocarpon pusillum is described from Spain and Australia as new to science. The new genus and species is compared with other taxa from the genera Didymellopsis and Zwackhiomyces (Xanthopyreniaceae, Collemopsidiales, Dothideomyceta), in particular with D. perigena, a species also having hyaline didymospores and also growing on Endocarpon. Rhagadodidymellopsis endocarpi is characterized by its almost completely superficial stromatic ascomata with a coarse and irregular surface, and an ascomatal wall of very irregular thickness, and ascospores smaller than those of D. perigena. We also compare the new species with other Endocarpon parasites, including Arthopyrenia symbiotica. This is a misunderstood species, originally described as Verrucaria symbiotica, which we also discuss in detail in this study.
\end{abstract}

Key words: Australia, new species, lichenicolous, Ascomycota, Spain, taxonomy

\section{Introduction}

Lichenicolous fungi are a specialized group of fungi that develop on lichens in a relatively inconspicuous way, with lifestyles ranging from parasymbiotic to necrotrophic parasitism and generally showing high specificity for their host (Diederich 2000). There are about 2320 species of lichenicolous fungi, described mostly within the Ascomycota, with less than $5 \%$ of the species belonging to the Basidiomycota. Authors claim, however, that up to 3000-5000 lichenicolous species could eventually be described (Diederich et al. 2018).

During study of the lichen diversity of Cap de Creus Natural Park in north-eastern Spain (Fernández-Brime 2012), we collected a lichenicolous fungus that was relatively abundant on the squamules of Endocarpon pusillum. The fungus was characterized by having fissitunicate asci, a hamathecium formed by abundant, branched and anastomosing, thin interascal filaments and one-septate hyaline ascospores, similarly to species of Didymellopsis or Zwackhiomyces (Grube \& Hafellner 1990). In these

\footnotetext{
${ }^{1}$ Department of Botany, Swedish Museum of Natural History, P.O. Box 50007, SE-104 05 Stockholm, Sweden

2 Jodrell Laboratory, Royal Botanic Gardens, Kew, TW9 3DS, UK

${ }^{3}$ Departament de Biologia Evolutiva, Ecologia i Ciències Ambientals (BEECA), Secció de Botànica i Micologia, Institut de Recerca de la Biodiversitat (IRBio), Facultat de Biologia, Universitat de Barcelona, Diagonal 643, ES-08028 Barcelona, Spain

* Corresponding author e-mail: samantha.fernandez@nrm.se
}

two genera, included in the family Xanthopyreniaceae (Collemopsidiales, Dothideomyceta; Pérez-Ortega et al. 2016), the ascomata are at least partially immersed in the host thallus, except for some Zwackhiomyces species that produce superficial ascomata (Calatayud et al. 2007) aggregated into a common stroma, and the ascomata wall thickness is uniform, sometimes becoming thicker towards the ostiole. Our specimens have consistently superficial ascomata with a characteristic coarse fissurate surface, grouped on a stromatic structure. In addition, the ascomatal wall is rather irregular and clearly thicker than the one in taxa from the above-mentioned genera. The latter macroscopic ascomatal features make this fungus resemble species of Rhagadostoma (Sordariomycetes), a genus distinguished by unitunicate asci and an evanescent hamathecium formed by thicker hyphae (Navarro-Rosinés \& Hladun 1994; Navarro-Rosinés et al. 1999) and therefore most probably not related to our fungus.

Based on the unique ascomata wall characteristics of our fungus, and as these traits do not fit any known genus, we propose to describe it as a new species and accommodate it in a new genus, Rhagadodidymellopsis.

For comparison, we have included in this study other lichenicolous fungi with bitunicate asci and hyaline, uniseptate ascospores growing also on Endocarpon. One of these is Verrucaria symbiotica, described by 
Nylander (1885), which was later combined in Arthopyrenia (Zahlbruckner 1922). This species develops perithecia completely immersed in the thallus of the host and has a smooth ascomata wall; hence it cannot be confused with the new Rhagadodidymellopsis endocarpi.

\section{Material and methods}

The specimens were examined morphologically and anatomically and are preserved in BCN, GRZ, H and NY (Thiers 2017), and in the personal herbarium of Javier Etayo. Macroscopic characters were examined using an Olympus SZ60 dissecting microscope. Microscopic characters were studied using a Zeiss Axioskop compound microscope. Hand-cut sections were mounted in water and stained with lactophenol cotton blue to increase the contrast of structures. Lugol's iodine solution with or without pre-treatment with $10 \%$ potassium hydroxide (K) was used to detect amyloid structures (indicated as I and K/I, respectively). Measurements were made only on dead herbarium material. Measurements of ascoma wall cells, asci and ascospores were made on material mounted in water; the values are the extreme values after rejecting $10 \%$ of the highest and lowest values; the highest and the lowest values are given in parentheses. For ascospore measurements the average value is also provided, in italics. The total number of measurements (n) is also given. Drawings were prepared with the aid of a drawing tube fitted to the microscope. Photographs were taken with a Pixera PRO150ES and an Olympus SC30 camera.

\section{Results}

Rhagadodidymellopsis Fdez.-Brime, Gaya, Llimona \& Nav.-Ros., gen. nov.

\section{MycoBank MB 835454}

Diagnosis: Ascomata black, perithecioid, unilocular, solitary or most commonly clustered inside a stromatic structure, with a clearly rugose and irregular surface, ascomal wall pseudoparenchymatous, blackish brown. Interascal filaments abundant, branched and anastomosing. Ostiolar filaments visible. Asci 8-spored, fissitunicate, thickened at apex, with distinct ocular chamber, clavate, stipitate. Ascospores hyaline, narrowly obovate to elongate ellipsoid, with smooth surface and conspicuous gelatinous sheath, 1-septate, markedly constricted at septum, heteropolar, with oil droplets. Asexual stage unknown.

Generic type: Rhagadodidymellopsis endocarpi Fdez.Brime, Gaya, Llimona \& Nav.-Ros.

Etymology. It refers to the fact that the stromatic ascomal wall resembles species of Rhagadostoma and that the spore features resemble species of Didymellopsis.

Ecology. Lichenicolous, growing superficially on the thallus of Endocarpon, so far only found on E. pusillum.

Rhagadodidymellopsis endocarpi Fdez.-Brime, Gaya, Llimona \& Nav.-Ros., sp. nov.

(Figs 1-3)

MycoBank MB 835455

Type: Spain, Catalonia, Girona, el Port de la Selva, punta de $S^{\prime}$ Arenella, $42^{\circ} 21^{\prime} \mathrm{N}, 3^{\circ} 10^{\prime} \mathrm{E}$, open siliceous soil crusts mixed with isolated schist rocks, $5 \mathrm{~m}$, on Endocarpon pusillum, 4 June 2011, S. Fernández-Brime 1155 \& X. Llimona (BCN-Lich. 18949 - holotype).

Description and diagnosis. A lichenicolous fungus not producing any apparent damage to the host. Vegetative hyphae not distinct. Ascomata stromatic, perithecioid, pseudothecia-type, black, superficial, with an irregular and markedly coarse surface, growing on the surface of the host squamules; young stromatic 150-300 $\mu \mathrm{m}$ in diam., \pm globose, unilocular, scattered on the host thallus, older stromatic ascomata $400-800 \mu \mathrm{m}$ in diam., irregularly flattened, grouped (up to 10 observed). Cells of the basal part of the stroma forming a continuum with the cells of the host cortex, from which they can only be distinguished by the colour of the cell walls, dark brown in the stroma and hyaline in the cortex; cells of the wall irregularly rounded to elongate when tangentially sectioned, mostly $(5-) 7-11(-16) \times(3.5-) 4-8 \mu \mathrm{m}$, wall pigments impregnating the cell wall, not forming granules, turning black with K. Ascomal wall pseudoparenchymatous, of textura angularis, blackish brown in both the upper and lower parts; wall in small unilocular ascomata $35-80 \mu \mathrm{m}$ thick in section, multi-layered, uniform in colour throughout their thickness, with the cell lumina of the external layers somewhat larger than those of more internal layers. Hymenial gel I-, K/I-. Interascal filaments abundant, branched and anastomosing, 1.5-2 $\mu \mathrm{m}$ wide. Ostiolar filaments visible near the ostiolar channel, $8-13 \times 1-1.5 \mu \mathrm{m}$. Asci (4-)8-spored, $(50-) 60-75 \times 13-16 \mu \mathrm{m}(\mathrm{n}=12)$, with the ascus wall thickened near the apex, with a distinct ocular chamber, clavate, stipitate, with ascospores distichously arranged; endoascus I-; dehiscence fissitunicate. Ascospores hyaline, narrowly obovate to elongated ellipsoid, with a smooth surface and a conspicuous gelatinous sheath (up to $1.5 \mu \mathrm{m}$ thick); only in some mature ascospores can finely granulose ornamentation be observed on the surface, 1-septate, markedly constricted at the septum, lower cell narrower than upper cell and attenuated, with one or two oil droplets per ascospore cell, (13-)15.5-17.1$19(-20.5) \times(5.5-) 6-7.0-8(-8.5) \mu \mathrm{m}[$ length/width ratio: $(2.0-) 2.1-2.5-2.7(-3.4)](\mathrm{n}=69)$. Conidiomata not seen.

Etymology. The 'endocarpi' refers to its host, the lichen genus Endocarpon.

Ecology and distribution. Up to date, only four collections from three localities of Rhagadodidymellopsis endocarpi are known. The type material was collected in north-eastern Catalonia (Spain) from several specimens of E. pusillum growing on siliceous clay soil in sun-exposed areas. Unlike other species living in the same locality, such as Epiphloea terrena and Gyalideopsis athalloides, Endocarpon pusillum is not ephemeral and does not become inconspicuous during dry periods. The other two samples were collected in Canberra (Australia), and also grow on typical E. pusillum.

Notes. In the genera Didymellopsis and Zwackhiomyces, the ascomata are usually produced solitarily, and the ascomatal wall thickness is uniform or slightly thicker towards the ostiole. Rhagadodidymellopsis endocarpi, 

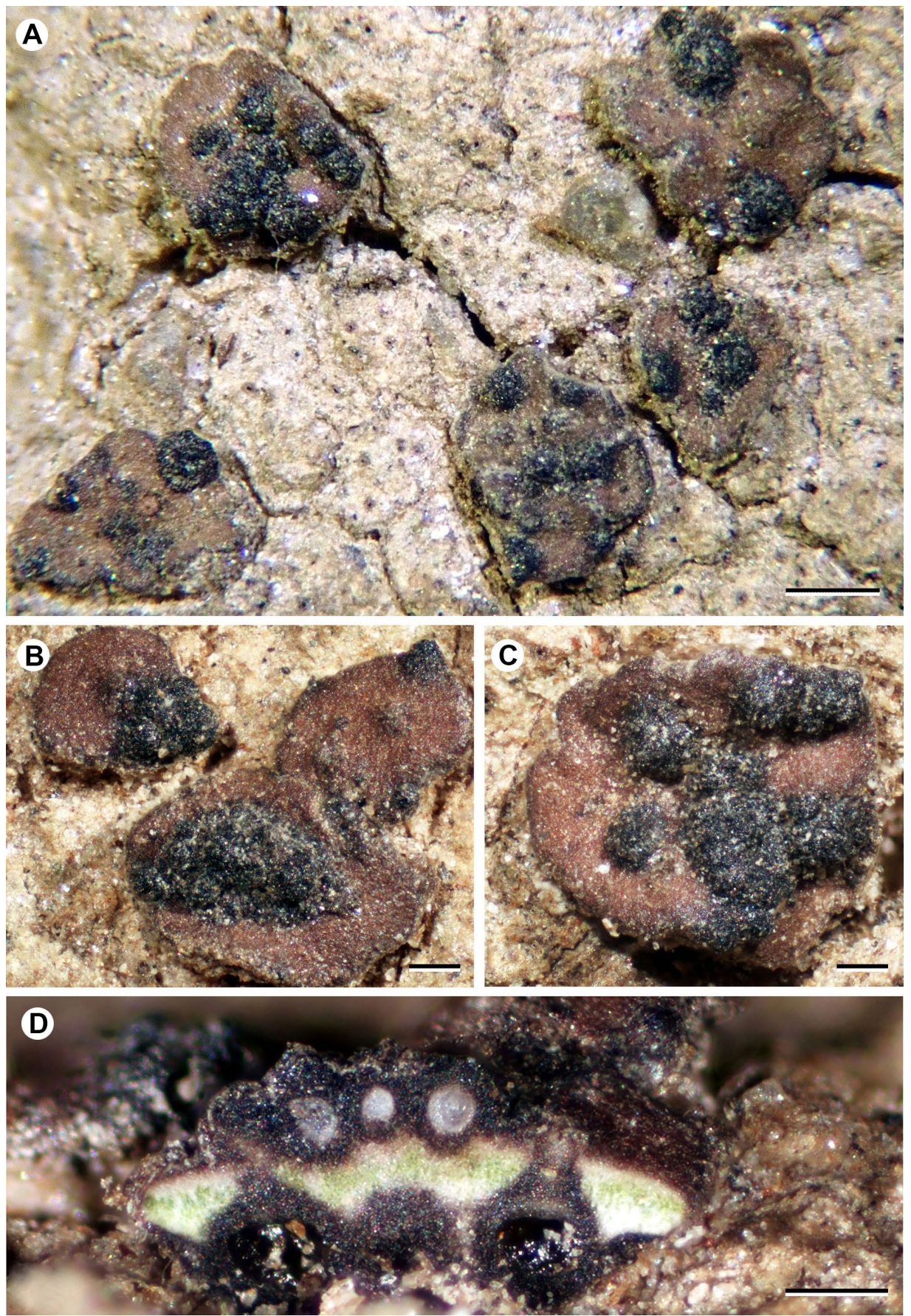

Figure 1. Rhagadodidymellopsis endocarpi (BCN-Lich. 18949, holotype). A-C - host thallus with R. endocarpi superficial ascomata; D - cross section of stroma-grouped ascomata. Scales: $A=500 \mu \mathrm{m} ; \mathrm{B}-\mathrm{D}=200 \mu \mathrm{m}$.

in contrast, has the ascomata mostly grouped in stromata, and the ascomatal wall varies in thickness around the grouped pseudothecia, resulting in a markedly rugose excipular surface.

Didymellopsis perigena also grows on Verrucariaceae species with a squamulose thallus. This species differs from $R$. endocarpi by having solitary, non-stromatic perithecioid ascomata (150-240 $\mu \mathrm{m}$ in diam.; fide Grube \& Hafellner 1990), an ascomal wall of rather constant thickness, 30-65 $\mu \mathrm{m}$ wide, longer ascospores, $18-25 \times 6-8.5 \mu \mathrm{m}$, with an average length/width value of $\sim 3$, and by growing mostly on the squamule margins of Placidium squamulosum (Grube \& Hafellner 1990; Khodosovtsev \& Klymenko 2015; see Table 1). Grube
\& Hafellner (1990) mentioned that D. perigena could grow not only on Placidium but also on Endocarpon, based on a record of 'Didymella' perigena from Nice (France) cited in Vouaux (1913). In Vouaux's study, the presence of flattened ascomata and ascospores of 15-21 $\times 6-8 \mu \mathrm{m}$ are mentioned. These features are fairly similar to those observed in $R$. endocarpi. However, it is also stated that the ascomata grow in the margin of the lichen squamules, which corresponds to the typical growth of $D$. perigena on the host thallus. Unfortunately, we were not able to locate Vouaux's specimen and therefore cannot determine whether the 'Didymella' perigena specimen described by Vouaux (1913) belongs to R. endocarpi or to $D$. perigena. 

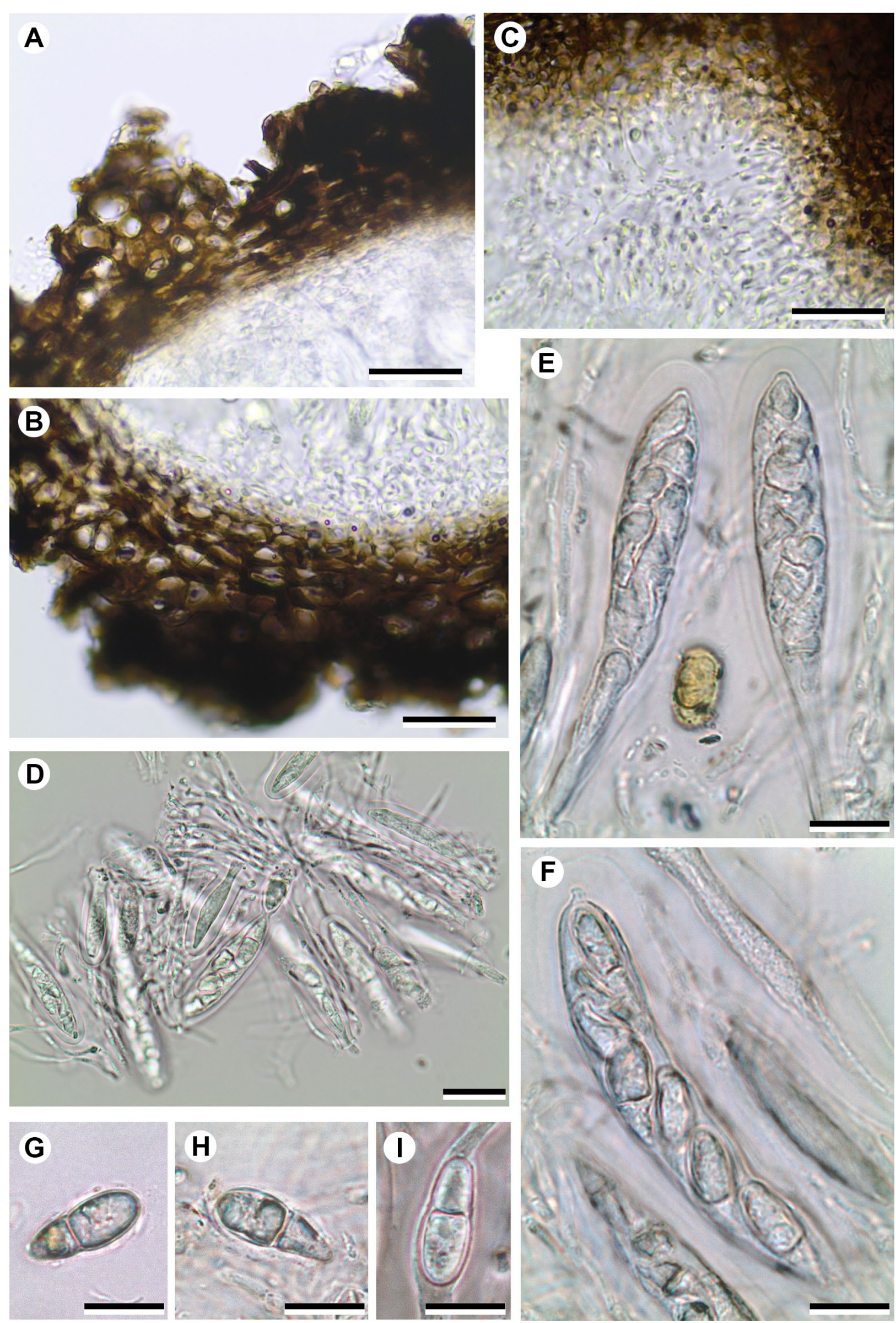

Figure 2. Rhagadodidymellopsis endocarpi (BCN-Lich. 18949, holotype) A-B - ascomal wall in cross section; C - ostiolar filaments close to ostiolar canal; D - asci and interascal filaments; E-F - asci with ascospores; G-I - ascospores. All microscopy sections mounted in water. Scales: $\mathrm{A}-\mathrm{D}=20 \mu \mathrm{m} ; \mathrm{E}-\mathrm{I}=10 \mu \mathrm{m}$. 

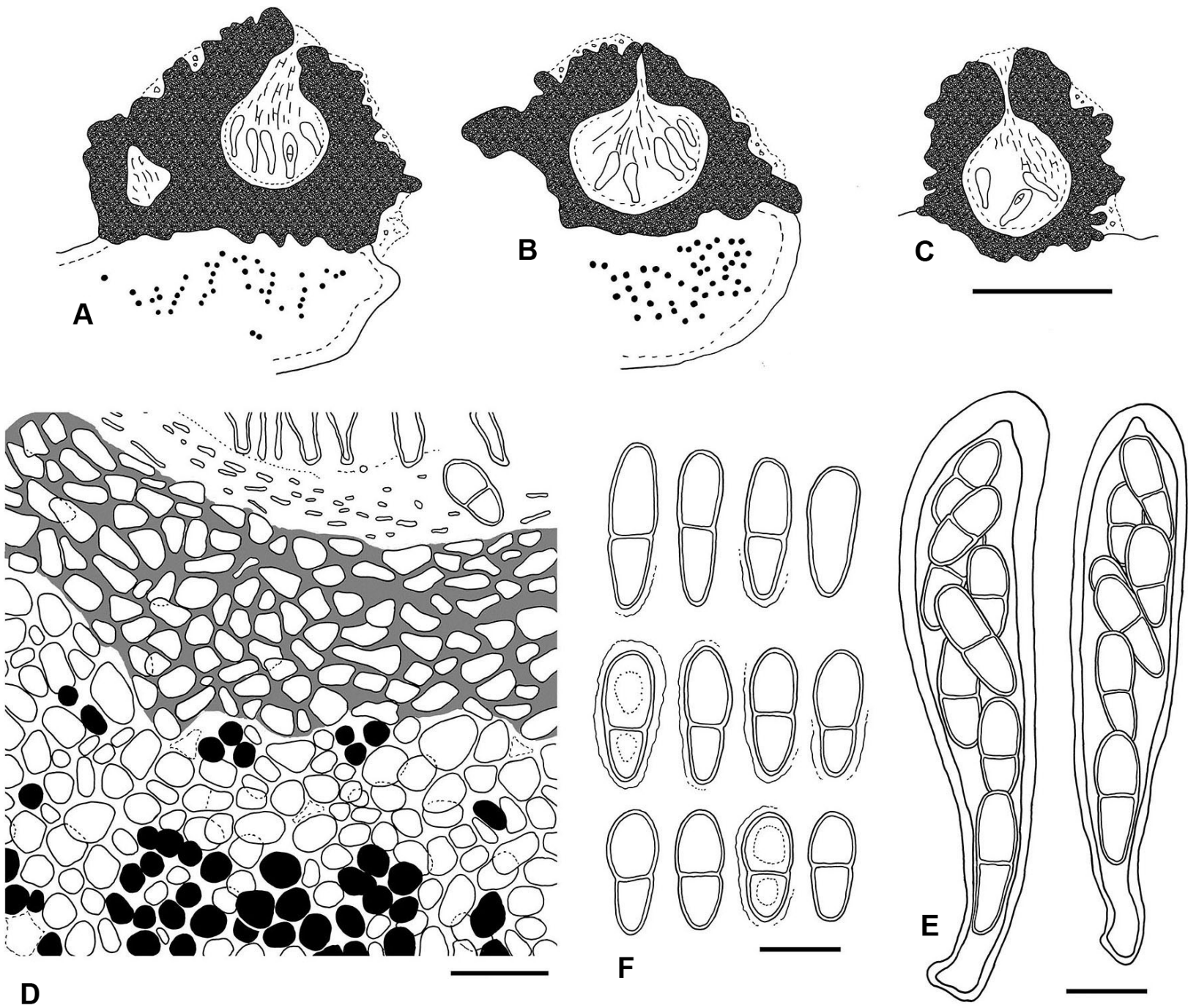

Figure 3. Rhagadodidymellopsis endocarpi (BCN-Lich. 18949, holotype) A-C - schematic sections of ascomata; D - basal part of ascomal wall (pigmented) forming a continuum with upper cortical layer of host (non-pigmented); E - asci with ascospores; F - ascospores. Scales: $\mathrm{A}-\mathrm{C}=200 \mu \mathrm{m} ; \mathrm{D}=20 \mu \mathrm{m} ; \mathrm{E}-\mathrm{F}=10 \mu \mathrm{m}$.

More recently, Yazic1 \& Etayo (2015) reported D. perigena in Turkey, growing on Endocarpon cf. pusillum. We revised this Turkish specimen and it matches well the description of $D$. perigena. There is a further citation of $D$. perigena from Cabo Verde (van den Boom 2012), potentially growing on E. pusillum, but as the author did not include morphological data regarding the lichenicolous fungus we cannot determine whether it corresponds to the newly described $R$. endocarpi or to D. perigena.

An additional ecological observation is that the irregularities on the surface of the stromata of Rhagadodidymellopsis endocarpi are always colonized by cyanobacteria, while no cyanobacteria are observed on lichen squamules devoid of the lichenicolous fungus. Based on this observation, we speculate that $R$. endocarpi might have a habit similar to the one mentioned by Grube \& Hafellner (1990) in D. perigena: these authors hypothesized that as $D$. perigena was the only species from the genus not growing on cyanolichens, it could establish symbiosis with cyanobacteria accumulated at the base of the ascomata and using the lichen only as a mere substrate.
If this was the case, the same relationship could occur in $R$. endocarpi, which would exploit the cyanobacteria accumulated in the irregularities of the stromata.

Additional specimens examined. AUSTRALIA. Australian Capital Terr.: Cotter Reserve, $\sim 20 \mathrm{~km} \mathrm{~W}$ of Canberra, $500 \mathrm{~m}$, 10 August 1988, H. Mayrhofer 8945 \& H. Streimann (GZU, Inv. Nr. 12-PO); Latham, $12 \mathrm{~km}$ NW of Capital Hill, Canberra, flat grassy verge beside the road, on bare semi-shaded ground, $35^{\circ} 13^{\prime} \mathrm{S}, 149^{\circ} 02^{\prime} \mathrm{E}, \sim 560 \mathrm{~m}, 9$ August 1993, H. Streimann 51974 (NY). SPAIN. Catalonia, Girona, El Port de la Selva, Punta de s'Arenella, open siliceous soil crusts with isolated schist rocks, $42^{\circ} 21^{\prime} \mathrm{N}, 3^{\circ} 10^{\prime} \mathrm{E}, 5 \mathrm{~m}, 4$ June 2011, S. Fernández-Brime 1156 \& X. Llimona (BCN-Lich. 18950).

Arthopyrenia symbiotica (Nyl.) Zahlbr., Catalogus Lichenum Universalis 1: 299(1921) (Figs 4A-E, 5)

Basionym: Verrucaria symbiotica Nyl., Flora (Regensburg) 68(15): 298(1885).

Type: France, Pyrénées-Orientales, Amélie-les-Bains, 'in semita ascendente rupium Mondoni [Montdony] supra Las Cascadas', 300 m, 24 March 1881, W. Nylander (H-NYL 874 - lectotype, designated here!, MycoBank MBT 392105). 

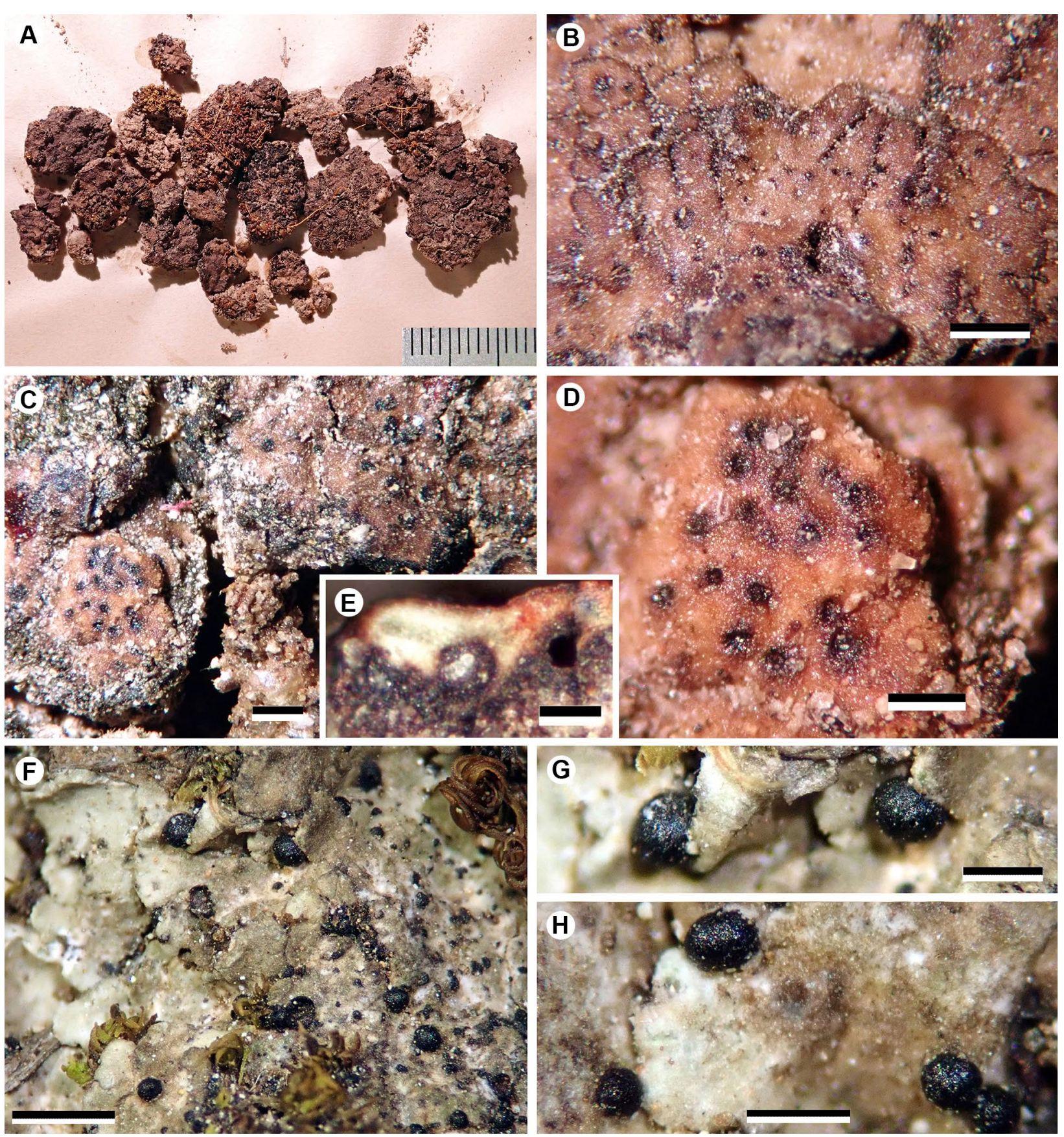

Figure 4. Arthopyrenia symbiotica (H-NYL874, lectotype; A-E) and Didymellopsis perigena (herb. Etayo 28700, F-H). A - type specimen of A. symbiotica (graphic scale, in $\mathrm{mm}$ ); B-D - host thallus with immersed ascomata of $A$. symbiotica, visible only by ostiolar area; E - ascoma in cross section immersed in host thallus; $\mathrm{F}-\mathrm{H}$ - superficial ascomata of $D$. perigena, located in margin of host thallus. Scales: A - in mm; B-C, $\mathrm{F}=500 \mu \mathrm{m} ; \mathrm{D}=300 \mu \mathrm{m} ; \mathrm{E}, \mathrm{G}-\mathrm{H}=200 \mu \mathrm{m}$.

$=$ ?Didymella pulposi var. garovaglii Vouaux, Bulletin de la Société Mycologique de France 29: 96(1913).

Type: France, près Beziers, sur le thalle de Endopyrenium garovaglii, s.d., A. de Crozals (TLON - type, non vid.).

$=$ ?Lichenochora hypanica S. Y. Kondr., L. Lökös et J.-S. Hur, Acta Botanica Hungarica 56(3-4): 361-368(2014).

Type: Ukraine, Mykolaiv oblast, Arbuzynka district, right bank of Pivdenny Buh River, near Konstantinovka village, $\sim 3-5 \mathrm{~km}$ lower along the river from Yuzhnoukrainsk town, near stone rapids on river, SE vertical surfaces of granite outcrops, at plots 22, 23 and 24 , in thalline squamules of Endocarpon obscuratum, $47^{\circ} 48^{\prime} 23^{\prime \prime} \mathrm{N}$, $31^{\circ} 10^{\prime} 10^{\prime \prime} \mathrm{E}$; 18 m, 17 May 2003, Kondratyuk, S. Y. 20311 and Fedorenko, N. M. (KW-L 70281 - holotype, non vid.).
Description. Ascomata perithecioid, from scattered to densely grouped or even confluent when abundant, completely immersed in host squamules, often reaching up to lower side of parasitized thallus, but only with reduced area of ostiole visible on upper side of squamules; unilocular, subglobose or pyriform in section, $\sim 150-220 \mu \mathrm{m}$ in diam; ascomata develop and mature completely immersed in host thallus, breaking host cortex when erupting, giving a crateriform aspect to ostiolar area. Ascomal wall $\sim(8-) 15-25(-30) \mu \mathrm{m}$ thick, formed by 3-6(-8) layers of cells; cells of stroma wall flattened in section, irregularly arranged, blackish brown, with cell wall pigment compact (not granular) and not uniformly distributed, generally less 
densely pigmented towards base of ascomata. Interascal filaments abundant, densely arranged, $2-3 \mu \mathrm{m}$ thick; after asci maturation, gelifying and emerging though ostiole. Asci 4(-8)-spored, 45-72 × 12-18 $\mu \mathrm{m}$. Ascospores hyaline, elongated ellipsoid or subfusiform, 1-septate, \pm constricted at septum, heteropolar, upper cell wider and rounded in tip, reaching maximum width towards half of cell, where slight constriction appears due to internal wall thickening, lower cell narrowing towards tip, giving bottle-like shape, $(20-) 21.5-23.2-25(-27) \times(6-) 6.5-7.1-$ $8(-9) \mu \mathrm{m}$ [length/width ratio: (2.7-)2.9-3.4-3.8(-3.9)] $(\mathrm{n}=24)$.
Notes. Arthopyrenia symbiotica is a barely known and misunderstood species growing on Endocarpon pallidum, for which we studied here the type specimen collected close to Amélie-les-Bains in southern France (Nylander 1985 , 1891). Besides the type material, we studied a more recent collection of $A$. symbiotica from Ablitas (northern Spain) growing on Endocarpon loscosii. This collection was initially identified as Didymellopsis perigena by Etayo (2008).

Didymellopsis perigena and Arthopyrenia symbiotica are taxa with very similar asci and ascospores, but they can be distinguished, as the first has globose and
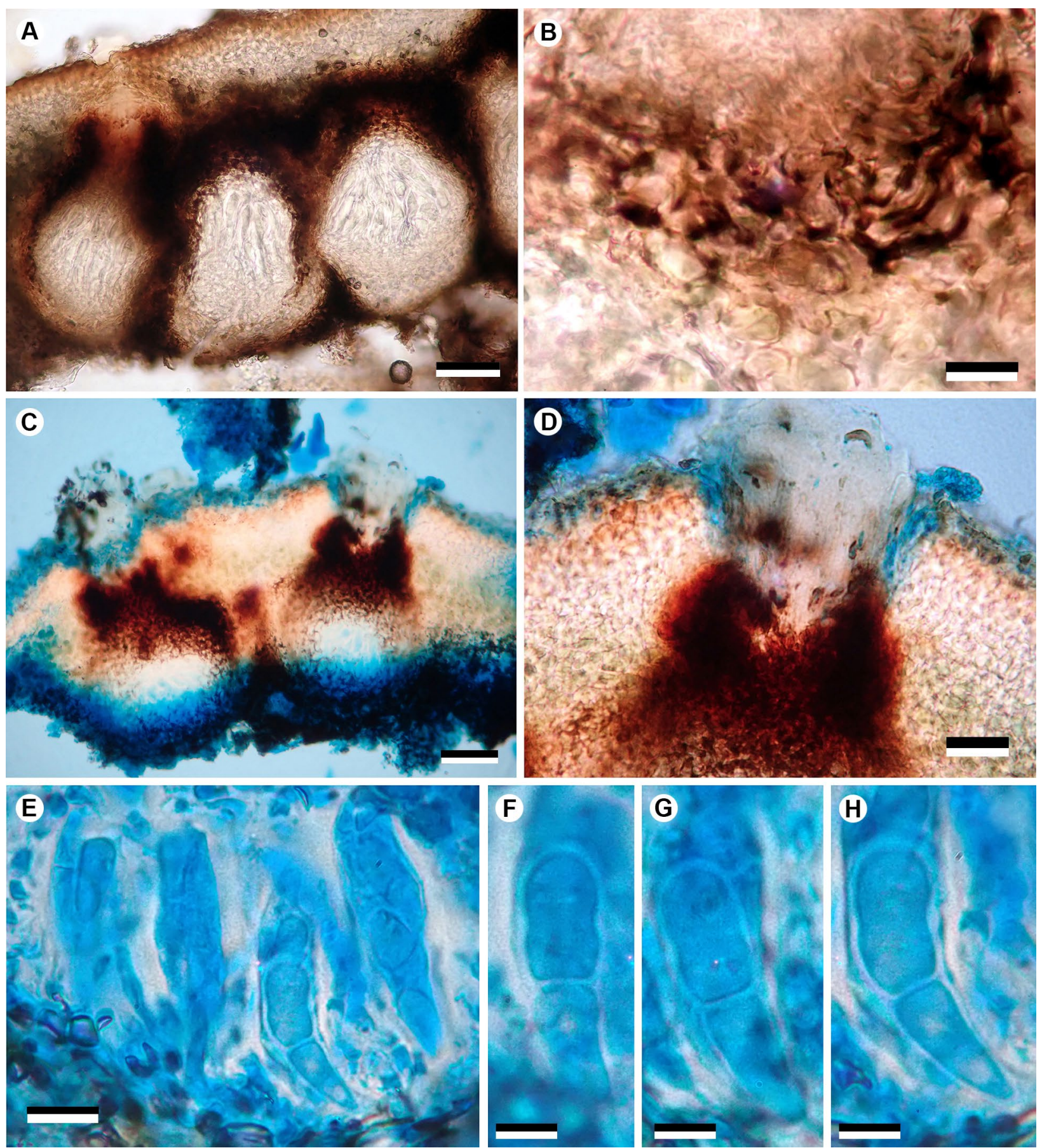

Figure 5. Arthopyrenia symbiotica (H-NYL874, lectotype). A - ascoma in cross section immersed in host thallus; B - basal part of ascomata wall (pigmented); C-D - ascomata in cross section with ostiolar area visible, where gelatinized hamathecium emerges; E -asci and interascal filaments; $\mathrm{F}-\mathrm{H}-$ ascospores. All microscopy sections mounted in water, $\mathrm{C}-\mathrm{H}$ also stained with lactophenol cotton blue. Scales: A, C $=50 \mu \mathrm{m}$; $\mathrm{B}=10 \mu \mathrm{m} ; \mathrm{D}-\mathrm{E}=20 \mu \mathrm{m} ; \mathrm{F}-\mathrm{H}=5 \mu \mathrm{m}$. 


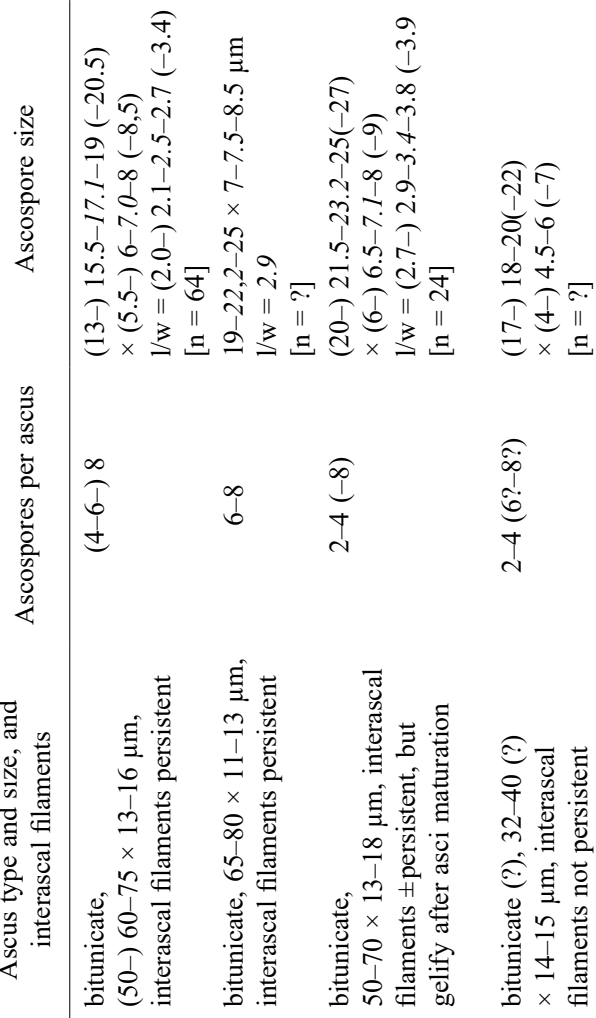

$\stackrel{Ð}{\rightleftarrows}$

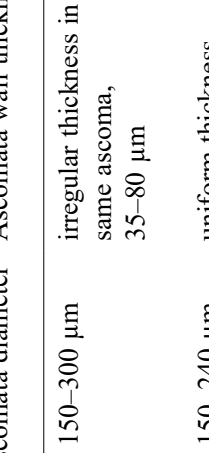

smooth-walled ascomata that grow almost completely superficially, mainly located at the margin of the squamules of the lichen host, while the latter has subglobose to pyriform ascomata that grow completely immersed in the host squamules.

Didymella pulposi var. garovaglii (Vouaux 1913) was considered a synonym of A. symbiotica by Roux et coll. (2017), and we follow this criterion here. The type material of this variety was also collected in southern France, close to Béziers, but growing on E. pusillum (Roux et coll. 2017). The description by Vouaux (1913) seems to be compatible with the characteristics we observed in the type material of $A$. symbiotica: ascomata growing completely immersed in the host thallus, 4-spored asci and ascospores $15-25 \times 7-10 \mu \mathrm{m}$, slightly wider than in our studied specimens. Due to the immersed position of the ascomata stated by Vouaux (1913), it seems feasible that Didymella pulposi var. garovaglii is in fact A. symbiotica. We cannot fully confirm this synonymy, however, as none of the Didymella pulposi var. garovaglii samples were found in the Vouaux Herbarium (MARSSJ).

Lichenochora hypanica (Kondratyuk et al. 2014) is another species growing on Endocarpon and with uniseptate, hyaline ascospores. Based on the characters provided in the original description, the morphology of L. hypanica does not correspond to that of the genus Lichenochora. Among other traits, Lichenochora has unitunicate asci and thick, irregular paraphyses that persist after the asci mature (Etayo \& Navarro-Rosinés 2008). However, in Kondratyuk et al. (2014) there is no reference to the ascus type and it is stated that interascal filaments are visible only in young ascomata. Lichenochora hypanica is similar to A. symbiotica in having the ascomata completely immersed in the host thallus, although it differs in having an evanescent hamathecium and smaller spores (Table 1). We have not been able to see the type material of L. hypanica, so its revision in relation to the taxa treated in this study must wait.

Artopyrenia symbiotica is then provisionally maintained in its current genus until further material can be studied.

Additional specimens examined. SPAIN. Navarra, Ablitas, sobre Endocarpon loscosii que crece en los suelos arcillosos de las lomas yesosas, cerca de una repoblación de pequeños pinos, $41^{\circ} 56^{\prime} 52.7^{\prime \prime} \mathrm{N}, 1^{\circ} 36^{\prime} 39.0^{\prime \prime} \mathrm{E}, 400 \mathrm{~m}, 15$ May 2005 , J. Etayo 22377 (herb. Etayo 22377).

Additional specimens of Didymellopsis and Zwackhiomyces examined. Didymellopsis perigena. TURKEY. Burdur, Altınyayla, Karanıkdere valley, $36^{\circ} 50^{\prime} 01^{\prime \prime} \mathrm{N}, 2^{\circ} 24^{\prime} 56^{\prime \prime} \mathrm{E}, 1392 \mathrm{~m}$, on Endocarpon cf. pusillum, 23 August 2013, K. Yazıc1 (herb. Etayo 28700; Figs 4F-H). Didymellopsis pulposi. SPAIN. Catalonia, Girona, Roses, Cala Jonculs, $42^{\circ} 15^{\prime} 14^{\prime \prime} \mathrm{N}, 3^{\circ} 15^{\prime} 19^{\prime \prime} \mathrm{E}$, siliceous soil crusts, on Scytinium teretiusculum (=Leptogium teretiusculum), 25 February 1984, X. Llimona \& N. L. Hladun (BCNLich). Zwackhiomyces coepulonus. SWITZERLAND. Valais, Trient, between Tête de Balme and la Croix-de-Fer, $0.6 \mathrm{~km}$ from French border, $2300 \mathrm{~m}$, calcareous wall $90^{\circ}$ inclination and facing NW, on Xanthoria elegans, 30 August 1988, P. Navarro-Rosinés (BCN-Lich). Zwackhiomyces physciicola. SPAIN. Catalonia, Girona prov., Roses, camí de Ronda, near la Punta Falconera, $42^{\circ} 14^{\prime} \mathrm{N}, 3^{\circ} 12^{\prime} \mathrm{E}$, granodiorite blocks $60^{\circ}$ facing $\mathrm{S}$, on Physcia dubia, 4 February 2003, X. Llimona (BCN-Lich). 


\section{Acknowledgements}

We thank the curators of the herbaria of BCN, GRZ, H and NY, and Dr. Javier Etayo for providing material used in this study. Dr. Paul Diederich and Dr. Mikhail Zhurbenko are thanked for their valuable comments which improved the quality of the manuscript. This study was carried out with support from the Institut d'Estudis Catalans (Secció de Ciències Biològiques) and the Fons de Recerca Salvador Llimona (Barcelona).

\section{References}

Calatayud, V., Triebel, D. \& Pérez-Ortega, S. 2007. Zwackhiomyces cervinae, a new lichenicolous fungus (Xanthopyreniaceae) on Acarospora, with a key to the known species in the genus. The Lichenologist 39: 129-134.

Diederich, P. 2000. Host-specificity and co-evolution in lichenicolous fungi, p. 102. In: Llimona, X., Lumbsh, T. H. \& Ott, S. (eds) The Fourth IAL Symposium, Progress and Problems in Lichenology at the Turn of the Millennium, Book of Abstracts. Universitat de Barcelona, Barcelona.

Diederich, P., Lawrey, J. D. \& Ertz, D. 2018. The 2018 classification and checklist of lichenicolous fungi, with 2000 non-lichenized, obligately lichenicolous taxa. The Bryologist 121: 340-426.

Etayo, J. 2008. Líquenes y hongos liquenícolas del LIC de Ablitas S Navarra, España. Cryptogamie, Mycologie 29: 63-94.

Fernández-Brime, S. 2012. Els líquens saxícoles i terrícoles del Parc Natural de Cap de Creus, amb un estudi filogenètic aplicat a la sistemàtica dels gèneres Diploschistes i Ingvariella. $\mathrm{PhD}$ Thesis, Universitat de Barcelona. http://hdl.handle.net/2445/45265

Grube, M. \& Hafellner, J. 1990. Studien an flechtenbewohnenden Pilzen der Sammelgattung Didymella (Ascomycetes, Dothideales). Nova Hedwigia 51: 283-360.

Khodosovtsev, A. Ye. \& Klymenko, V. M. 2015. Didymellopsis perigena (Nyl.) Grube and Zwackhiomyces cervinae Calat., Triebel \& Pérez-Ortega (Xanthopyreniaceae, Ascomycota) new for Ukraine species of the lichenicolous fungi. Chornomorski Botanical Journal 11: 217-222.
Kondratyuk, S. Y., Lőkös, L. \& Hur, J.-S. 2014. New lichen-forming and lichenicolous fungi from Ukraine. Acta Botanica Hungarica 56: 361-368.

Navarro-Rosinés, P. \& Etayo, J. 2008. Una combinación y tres especies nuevas de Lichenochora (Phyllachorales, ascomicetes liquenícolas), y notas adicionales para el género. Revista Catalana de Micologia 30: $27-44$.

Navarro-Rosinés, P. \& Hladun, N. L. 1994. Datos sobre el género Rhagadostoma (Ascomicetes liquenícolas, Sordariales). Bulletin de La Société Linnéenne de Provence 45: 431-442.

Navarro-Rosinés, P., Etayo, J. \& Calatayud, V. 1999. Rhagadostoma collematum sp. nov. (Ascomicetes liquenícolas, Sordariales) y nuevos datos para otras especies del género. Bulletin de la Société Linnéenne de Provence 50: 233-241.

Nylander, W. 1885. Addenda nova ad Lichenographiam Europaeam. Continuatio quadragesima quarta. Flora (Regensburg) 68: 295-301.

Nylander, W. 1891. Lichenes Pyrenaeorum Orientalium obsevatis novis (Amélie-les-Bains, Forca-Réal, Costabonne, La Massane, Collioure). P. Schmidt, Paris.

Pérez-Ortega, S., Garrido-Benavent, I., Grube, M., Olmo, R. \& de los Ríos, A. 2016. Hidden diversity of marine borderline lichens and a new order of fungi: Collemopsidiales (Dothideomyceta). Fungal Diversity 80: 285-300.

Roux, C. et coll. 2017. Catalogue des lichens et champignons lichénicoles de France métropolitaine. 2e édition. Association française de lichénologie, Fontainebleau.

Thiers, B. 2017. Index Herbariorum: a global directory of public herbaria and associated staff. New York Botanical Garden's Virtual Herbarium. http://sweetgum.nybg.org/ih/. [10/5/2017]

Van den Boom, P. P. G. 2012. Additions and notes to the checklist of lichens and lichenicolous fungi of Cape Verde. Österreichische Zeitschrift für Pilzkunde 21: 5-16.

Vouaux, L. 1913. Synopsis des champignons parasites de lichens (Suite). Bulletin de la Société Mycologique de France 29: 33-128.

Yazıcı, K. \& Etayo, J. 2015. The lichenicolous fungi of Burdur province in Turkey. Mycotaxon 130: 1214

Zahlbruckner, A. 1922. Catalogus lichenum universalis 1. Verlag von Gebrüder Borntraeger, Leipzig. 